\title{
DEVELOPMENT OF STUDENTS' SELF-CONSCIOUSNESS BY THE MEANS OF UKRAINIAN LITERATURE
}

UDC: $159.923 .2: 821.161 .2-057.87$

\section{Kazibekova Viktoriia \\ Ph.D. in Psychology, Assistant professor, Assistant professor of the Department of Practical Psychology Kherson State University, Kherson (Ukraine) \\ ORCID ID: https://orcid.org/0000-0001-8707-2514}

\section{Samkova Olesia}

Ph.D. in Psychology, Senior Lecturer of the Department of Practical Psychology Kherson State University, Kherson (Ukraine)

ORCID ID: https://orcid.org/0000-0001-8572-9113

\section{SUMMARY}

«Development of Student' Self-Consciousness by the means of Ukrainian Literature». The article describes the educational formative experiment, aimed at development of students' national selfconsciousness by the means of active acquirement by them of material and mental national culture, and analyses its results.

The performed educational experiment and the following statistical analysis of its results have presented a strong case that highly developed national self-consciousness of the group of students Ukrainian philologists, and the increase of self-consciousness level in the experimental groups are conditioned by the influence of the interactive, problem searching, audible educational and reconstructive, deeply psychological, and cathartic learning in the Ukrainian literature and other subjects within the academic course of Ukrainian studies.

The increased in volume and deepened learning of Ukrainian literature, language and other subjects within the academic course of Ukrainian studies, the strengthening of the national orientation of the academic courses in pedagogy, psychology, cultural studies, special educational courses and educational work influence greatly on an individual's emotional and sensitive sphere, and through it on their intellectual and morally-valuable spheres, which effectively contributes to the development of 
students' national self-consciousness and civic consciousness, even those students, who are the representatives of other ethnic societies.

Key words: national consciousness and self-consciousness, civic consciousness (civicizm), spirituality, Ukrainian literature, development.

The performed educational experiment and the following statistical analysis of its results have presented a strong case that highly developed national self-consciousness of the group of students - Ukrainian philologists, and the increase of self-consciousness level in the experimental groups are conditioned by the influence of the interactive, problem searching, audible educational and reconstructive, deeply psychological, and cathartic learning in the Ukrainian literature and other subjects within the academic course of Ukrainian studies.

The increased in volume and deepened learning of Ukrainian literature, language and other subjects within the academic course of Ukrainian studies, the strengthening of the national orientation of the academic courses in pedagogy, psychology, cultural studies, special educational courses and educational work influence greatly on an individual's emotional and sensitive sphere, and through it on their intellectual and morally-valuable spheres, which effectively contributes to the development of students' national self-consciousness and civic consciousness, even those students, who are the representatives of other ethnic societies.

Formulation of the problem. Today, an individual's spiritual development is particularly important for Ukraine. The system of values can influence on successful character education of young people under the condition when the educational process will be performed in the national direction. First of all, it provides the formation of the young generation's spirituality within the context of national consciousness and selfconsciousness.

One of the conditions for the successful education of modern youth is a return to the spiritual roots of Ukrainian people, to the cultural traditions of the Ukrainians and Ukrainian national pedagogy, which, according to G. Skovoroda, is the basis for the formation of Ukrainian "Self" on the basis of the knowledge of own people and themselves.

The national consciousness means a person's (a nation's) self-perception, self-evaluation as a bearer of national values, which were formed in the process of historical development of society, self-realization as an community agent, eager for self-affirmation, occupying a proper place among other national societies and making a worth contribution to the civilization progress of humanity [1].

Language, history, beliefs, folklore, art, traditions and customs, symbolism, signs are often called among the national school components 
[1]. To the greatest extent, almost all of these components are present in literature, which can be considered as a universal space-time art form. Such universality is created through language the language is able to convey temporal, spatial, colour, relief, and all sorts of other features of objects and phenomena. Literature has the most powerful influence on the development of human spirituality and national self-consciousness.

For a long time, the state policy in the field of youth education was aimed at destroying the national identity, the entire national-cultural way of life of the Ukrainians, bringing to oblivion the historical memory, destroying Ukrainian folk traditions, morals, language and customs. Now all this matters needs rethinking, and the content of education should be updated as a complete system in accordance with modern requirements, thanks to which the younger generation masters the achievements of previous generations, cognizes the societal heritage of the native people, its national character, the peculiarities of the world perception, the national way of thinking.

The national self-consciousness means not only an ethnic group's capability to represent itself, to separate itself from other ethno-national formations, but also a person's capability to be aware of him/herself at the ethnic-psychological space, to feel like an ethnic agent, to realize own ethnic particularities, to have a formed feeling of ethnic identity and ethno-national understanding.

Literature plays a leading role in national consciousness and self-consciousness formation as a form of the cultivation of national language, traditional standards of behaviour, national ethics, samples of national character, view of life, national ideals, etc. [2].

The study covered 360 students of Kherson State University, aged 16 to 26 years. Of the entire sample, 120 individuals studied at the Institute of Ukrainian Philology and Journalism, where Ukrainian literature and language are taught as a specialty, a large amount of academic hours are allocated to it; other students studied at other faculties where Ukrainian literature is taught only a limited number of hours (Faculty of Culture and Arts - 60 people; Institute of Foreign Philology - 60 people) or not taught at all (Faculty of Economics and Law - 60 students; Institute of Natural Sciences - 60 people). Thus, we divided all the respondents into three groups according to whether or not they learn Ukrainian literature and other disciplines of the academic course in Ukrainian studies and to what extent. The first group consisted of the students of Faculty of Economics and Law and the Institute of Natural Sciences. The second group included the students of the Faculty of Culture and Arts and the Institute of Foreign Philology. The third group consisted of the students of the Institute of Ukrainian Philology and Journalism.

\section{Analysis of recent research and publi-}

cations. The problem of the value system of contemporary education, its humanistic orientation, openness to world and national culture is being elaborated in the scientific studies of many fa- 
mous philosophers, psychologists and pedagogues: V.P. Andrushchenko, G.O. Ball, I.D. Bekh, M.Yo. Boryshevskyi, V.S. Vozniak, A.F. Zakharchiuk, Z.S. Karpenko, S.D. Maksymenko, V.P. Moskalets, A.V. Furman, N.V. Chepelieva, V.M. Chernobrovkina and others.

The theoretical grounds of the educational experiment are the scientific and empirical works of such modern scientists as M.Yo. Boryshevskyi, G.V. Lokarieva, V.P. Moskalets, L.E. Orban -Lembryk, N.M. Saveliuk, L.D. Todoriv and others, who illustrate the mechanisms of educational influence of literary and esthetical content of art, especially influence of literature on different structures of personality $[2 ; 3 ; 4]$.

The educational experiment was performed with the purpose to verify effectiveness of literary and esthetical, ideological and emotional influence of the works of national (Ukrainian) literature and other subjects of the academic course in Ukrainian studies on national feelings, thoughts, values, ideals and, in the same way, on the students' self-consciousness development.

During the formative experiment we have found out that the respondents, learning Ukrainian literature, language, Ukrainian folk art, history and soul of native nation in general in the large volume, have the higher level of national selfconsciousness development, they show more emotional and, at the same time, more responsible attitude toward themselves as the bearers of the characteristics and particularities of the Ukrainian nation. We have performed the experi- ment with the view to determine whether the high level of national self-consciousness in third group of the respondents is caused, particularly, by influence of more intensive, «involved» study of Ukrainian literature and other subjects of the academic course in Ukrainian studies.

The purpose of the article is to present the results of the formative experiment. The intentional development of national selfconsciousness of Ukrainian youth demands the solution of the following problems: 1) assistance to the active acquisition by the students of material and intellectual culture of their nation; 2) guaranteed learning on psychological particularities of the typical nation representatives; 3) deepening of youth's awareness on their nation history, stimulation of their interest in the historical past and the concerning about the future of their own national society.

The students of the second group with the determined low and middle levels of national self -consciousness were involved into the experiment. We selected the students exactly of this group because, first of all, among the compulsory educational subjects, they studied the history of world culture, where one of the chapters was the history of Ukrainian culture (including literature), i.e. these students were ready for understanding of literary works; in the second place, according to the research findings of national selfconsciousness, the indexes in this group are intermediate between the first and third groups; and in the third place, the biggest number of representa- 
tives of different nationalities is among the second group respondents.

Presentation of the main material. 60 persons participated in the educational experiment -30 students from the culture and arts faculty and 30 students from the foreign languages and translation studies faculty. We divided them into two combined equal subgroups, choosing in a random manner, but in such a way that both subgroups included the same number of persons with the middle and low levels of national selfconsciousness. The first subgroup we figuratively called the experimental group A, the second the experimental group B (hereinafter simply the group A and the group B). Consequently, the initial indexes of both experimental groups were distributed identically (see table 1). of the group A and B. Namely: the more intensive motivational influence on feelings, thoughts, ideals, values of respondents, the more effective development of national self-consciousness, which must be reflected in the increase of national self-consciousness indexes during the repeated examination.

According to the assignments of the educational experiment we elaborated the special course «Ukraine and the Ukrainians in literature and art». The contextual orientation of the special course was the stimulation in students of emotional and sensitive, valuable and sense bearing mechanisms during the active learning (interiorization) of the works of Ukrainian literature and art that could help us understand the criteria whereby the young people can identify

Table 1

The previous distribution of the indexes of national self-consciousness in the experimental groups

\begin{tabular}{|c|c|c|c|}
\hline \multirow{2}{*}{} & \multicolumn{3}{|c|}{ Levels of national self-consciousness (as \%) } \\
\cline { 2 - 4 } & high & middle & low \\
\hline Experimental group A & - & 87 & 13 \\
\hline Experimental group B & - & 87 & 13 \\
\hline
\end{tabular}

During the educational experiment we were guided by the hypothesis that the influence on respondents of the identical stimuli (the works of Ukrainian literature and certain topics from other subjects of the Ukrainian studies), but with different intensities (and, therefore, understanding and interiorization were also different), would cause the specific contradictions in dynamic of national self-consciousness of students themselves with the representatives of their national society: historical past, traditions, habits, material and intellectual culture of Ukrainian people, national character of the Ukrainians, mental particularities.

In the process of the educational experiment the students of the groups A and B during the semester were studying this course as an elective course. The classes were given once a 
week for the group A and on a semi-monthly basis for the group B. In addition, for each group, we presented the thematic lessons of academicians of Kherson State University, which took place on a semi-monthly basis according to the plan. Thus, the directed teaching and educational influence duration was equal to 50 for the group A, and 30 hours for the group B (2 academic hours for each class, 1 hour for thematic academician lessons). Consequently, the both groups heard the special course with the same program, but with the different intensity. The remarkable thing is, that, the both groups attended together some classes and academician lessons.

The respondents studied the literary works and other stimulus material using different forms of work: independent exploration and work selection according to the specific theme; grouped reading with the comments and the follow-up discussion; composition of the vocabularies of Ukrainian national character traits; literary analysis of the particularities of author's language of different works; psychological and characterological analysis of literary heroes; dramatization of certain episodes; declamation of poesy and prosa- ic fragments; making of national costumes, dishes; presentation of the elements of Ukrainian traditional ceremonies; writing of discursive essays, etc. We tried to engage the students maximally emotionally in participation in different forms of work with the literary material, and, during the educational hours, to stimulate the self-dependent formation of new life senses.

At the end of the special course we determined national self-consciousness development of the group A and B students, re-using the methods of V. Borysov and D. Tkhorzhevskyi. We obtained the following results: in the group A, $12 \%$ of the respondents had high national selfconsciousness, $81 \%$ of them had have the middle level, $7 \%$ had the low level; in the group B, 9\% of the respondents had high national selfconsciousness, $81 \%$ had the middle level, $10 \%$ of respondents had low national self-consciousness.

To trace the dynamics of national selfconsciousness we compared the results of the group A and B students, obtained before and after the educational experiment (see table 2).

As can be seen from the table, there are differences between the indexes of national self-

Table 2

The dynamics of the national self-consciousness indexes in the groups $A$ and $B$

\begin{tabular}{|l|c|c|c|c|c|c|}
\hline \multirow{3}{*}{ Groups of students } & \multicolumn{5}{|c|}{ National self-consciousness (as \%) } \\
\cline { 2 - 8 } & \multicolumn{2}{|c|}{ high } & \multicolumn{2}{c|}{ middle } & \multicolumn{2}{c|}{ low } \\
\cline { 2 - 7 } & before EE & after EE & before EE & after EE & before EE & after EE \\
\hline A (50 EE hours) & - & 12 & 87 & 81 & 13 & 7 \\
\hline B (30 EE hours) & - & 9 & 87 & 81 & 13 & 10 \\
\hline
\end{tabular}

Note: EE-educational experiment 
consciousness before and after the educational experiment for the both group A and B, i.e. there is an increase of national self-consciousness, indeed we should remind that before the educational experiment there wasn't any respondent with high national self-consciousness.

Thus, we can make a conclusion about the effectiveness of the influence on national feelings, thoughts, values, ideals, national selfconsciousness and identity, as well as on the civil qualities of students of such means of Ukrainian literature as literary and esthetical, ideological and emotional content of its prose and lyric works, their ethnic unique metaphoricity, literary and emotional expressiveness of Ukrainian language, which the students had internalized during the special active, positive and emotional activities.

For checking of the program effectiveness and understanding of the differences, revealed between the national self-consciousness indexes of the groups A and B at the end of the educational experiment, as well as for the determination of influence of the special course intensity on national self-consciousness, we used the statistical methods, namely, the statistical Student's t-test. We compared the results, obtained before and after the educational experiment in the groups $\mathrm{A}$ and B, by Student's t-test for the dependent samples, and the results between the groups A and B after the educational experiment by the Student's $t$ -test for the independent samples.

According to the Student's t-test for the group A, the respondents of which were studying the special course for 50 hours, the average value of the national self-consciousness indexes after the educational experiment is statistically higher than the average value before the educational experiment with the significance level of $\mathrm{p}<0,01$. So, we can see the statistically significant increase of national self-consciousness in the group A.

As for the group $\mathrm{B}$, the respondents of which studied the special course for 30 hours, $t$ criterion shows that the average value after the educational experiment is also statistically higher than the average value of the national selfconsciousness indexes before educational experiment, but with the significance level of $p<0,05$. Anyway, national self-consciousness increase in the group B is statistically significant $(p<0,05)$.

As we can see, the respondents of the both groups $\mathrm{A}$ and $\mathrm{B}$ have the positive dynamics of the national self-consciousness at the end of the educational experiment, but its intensity is not the same. For the final check of the probability of these differences, we compared the repeated measurements of national self-consciousness in the groups A and B with the t-criterion. The average value of the national self-consciousness indexes after the educational experiment in the group A is statistically higher than that in the group B with the significance level of $p<0,05$. Thus, according to the statistics, national selfconsciousness of the group A respondents was increased higher than that of the group B re- 
spondents, and the identified differences was equal to $5 \%$.

Besides, there is a high correlation (in the group A r $=0,896$, in the group $\mathrm{B} r=0,859$, in both groups $p<0,001)$ between the indexes of national self-consciousness of the students before and after the educational experiment in the both groups A and B. It is evidence that if the initial national self-consciousness of a respondent was higher before the experiment, than it is also higher at the end of the educational experiment.

In our opinion, the determined statistically high correlations between the initial and final national self-consciousness indexes in both experimental groups also proves the effectiveness of the influence of Ukrainian literature and other subjects of Ukrainian studies on the respondents' national self-consciousness development.

Conclusion. The performed educational experiment and the following statistical analysis of its results have presented a strong case that high national self-consciousness in the students Ukrainian philologists, and the increased national self-consciousness in the experimental groups can be associated with the influence of the interactive, problem searching, audible educational and reconstructive, deeply psychological, and cathartic learning in the Ukrainian literature and other subjects within the academic course of Ukrainian studies.

The increased in volume and deepened learning of Ukrainian literature, language and other subjects within the academic course of
Ukrainian studies, the strengthening of the national orientation during the academic courses in pedagogy, psychology, cultural studies, special educational courses and educational work influence greatly on an individual's emotional and sensitive sphere, and through it on their intellectual and morally-valuable spheres, which effectively contributes to the development of students' national self-consciousness and civic consciousness, even those students, who are the representatives of other ethnic societies.

By taking into account the specifics of professionally oriented higher education, we should consider various forms of extracurricular and educational work with students as a powerful basis for the effective development of national self-consciousness. These forms are:

- familiarization with the life, social, political, scientific, educational and artistic achievements of famous representatives of the Ukrainian people of the past and present;

- re-creation of Ukrainian national customs, traditions, originality of life and way of life, ethics of human relations in such interactive forms as amateur theatrical productions with creation of Ukrainian national costumes, literary and musical evenings, «Cossack entertainments», «Ukrainian nights» and the like;

- active searching of the works in line with the research and local lore activities of the student circles; 
- active introduction of innovative achievements of the modern Ukrainian scientists and artists during practical training and so on.

\section{References (Transliteration):}

Boryshevskyi M.I.(2000). Natsionalna samosvidomist $u$ hromadianskomu formuvanni osobystosti. [National self-consciousness in the civil formation of personality]. Kyiv: Berkut [in Ukrainian].

Lokarieva G.V.(2006). Literaturna ta estetychna informatsiia yak zasib vykhovannia studentiv [Literary and esthetical information as a means of education of students]. Mystetstvo ta osvita - Art and education, I, 7-11 [in Ukrainian].

Moskalets V.P., Iurchenko I.V. (2000). Literaturno-tvorcha diialnist yak zasib osobystisnoho samorozvytku uchniv starshykh klasiv [Literary and creative activity as a means of personal self-development of high school students]. Problemy zahalnoi ta pedahohichnoi psykholohii - Problems of general and pedagogical psychology, (Vols 3), (pp.105-109), Kyiv:Volynia amulets[in Ukrainian].

Saveliuk N.M.(2008) Systema tsinnisnykh oriientatsii suchasnykh studentiv yak sens nesuchoi osnovy hromadianskoi svidomosti [System of valuesbased orientations of contemporary students as a sense bearing basis of civic awareness]. Aktualni problemy vykhovannia $\mathrm{v}$ humanitarnykh naukakh: zbirka naukovykh prats / Pid zahalnoiu redaktsiieiu Onkovycha H.V. i Lomakovych A.M. - Current problems of the education in the humanities: collection of scientific works/ Under the general editorship of Onkovych G.V. and Lomakovych A.M., (Vols.4), (pp.137-143), Kyiv - Kremenets: PPC of KRAHPS named after Taras Shevchenko [in Ukrainian].

\section{Казібекова Вікторія Федорівна}

Кандидат психологічних наук, доцент кафедри практичної психології Херсонського державного університету, м. Херсон (Україна)

\section{Самкова Олеся Миколаївна}

Кандидат психологічних наук старший викладач кафедри практичної психології Херсонського державного університету, м. Херсон (Україна)

\section{РОЗВИТОК НАЦІОНАЛЬНОЇ САМОСВІДОМОСТІ СТУДЕНТІВ ЗАСОБАМИ УКРАЇНСБКОЇ ЛІТЕРАТУРИ}

Анотація. Сьогодні для України розвиток духовності є особливо актуальним. Система цінностей може слугувати успішному вихованню особистості громадянина за умови, коли виховний процес здійснюватиметься в національному руслі. Передусім це передбачає формування у молодого покоління духовності в контексті національної свідомості і самосвідомості.

Серед складових національної школи найчастіше зазначають мову, історію, вірування, фольклор, мистецтво, традиції і звичаї, символіку, прикмети. Найбільшою мірою усі ці складові відображаються в літературі, яку можна вважати універсальним просторовочасовим видом мистецтва. Така універсальність створюється за допомогою мови - мова здатна передати тимчасові, просторові, кольорові, рельєфні і всілякі інші особливості предметів і явищ. Саме література здатна наймогутніше впливати на розвиток духовності і національної самосвідомості людини. 
Формувальний експеримент здійснювався з метою експериментальної перевірки ефективності художньо-естетичного, ідейноемоційного впливу творів української літератури і дисциплін українознавчого циклу на національні почуття, думки, цінності, ідеали і тим самим на розвиток національної самосвідомості студентів.

Проведений формувальний експеримент і подальша математико-статистична обробка отриманих результатів переконливо довели, що збільшення об'єму і глибини вивчення української літератури, мови і інших дисциплін українознавчого циклу, посилення національної орієнтації курсів педагогіки, психології, культурології, учбових спецкурсів і виховної роботи впливають на емоційночуттєву, а через них на розумову і моральноціннісну сфери особистості, що ефективно сприяє розвитку національної самосвідомості у студентів.

Ключові слова: національна свідомість і самосвідомість, громадянська свідомість, духовність, українська література, розвиток.

\section{Казибекова Виктория Федоровна}

Кандидат психологических наук, дочент кафедры практической психологии Херсонского государственного университета, г. Херсон (Украина)

\section{Самкова Олеся Николаевна}

Кандидат психологических наук, старший преподаватель кафедры практической психологии Херсонского государственного университета, г. Херсон (Украина)

\section{РАЗВИТИЕ НАЦИОНАЛЬНОГО САМОСОЗНАНИЯ СТУДЕНТОВ СРЕДСТВАМИ УКРАИНСКОЙ ЛИТЕРАТУРЫ}

Аннотация. Сегодня для Украины развитие духовности является особенно актуальным. Система ценностей может служить успешному воспитанию личности гражданина при условии, когда воспитательный процесс будет осуществляться в национальном русле. Прежде всего это предусматривает формирование у молодого поколения духовности в контексте национального сознания и самосознания.

Среди составляющих национальной школы чаще всего называют язык, историю, верования, фольклор, искусство, традиции и обычаи, символику, приметы. В наибольшей степени все эти составляющие отображаются в литературе, которую можно считать универсальным пространственно-временным видом искусства. Такая универсальность создается посредством языка - язык способен передать временные, пространственные, цветные, рельефные и всевозможные другие особенности предметов и явлений. Именно литература способна наиболее мощно влиять на развитие ду- 
ховности и национального самосознания человека.

Формирующий эксперимент осуществлялся с целью экспериментальной проверки эффективности художественно-эстетического, идейно-эмоционального влияния произведений украинской литературы и дисциплин украиноведческого цикла на национальные чувства, мысли, ценности, идеалы и тем самым на развитие национального самосознания студентов.

Проведенный формирующий эксперимент и последующая математикостатистическая обработка полученных результатов убедительно доказали, что увеличение объема и глубина изучения украинской литературы, языка и других дисциплин украиноведческого цикла, усиление национальной ориентации курсов педагогики, психологии, культурологии, учебных спецкурсов и воспитательной работы влияют на эмоциональночувственную, а через них на умственную и нравственно-ценностную сферы личности, чем эффективно содействуют развитию национального самосознания у студентов.

Ключевые слова: национальное сознание и самосознание, гражданское сознание, духовность, украинская литература, развитие.

\section{Kazibekova Viktoriia}

Ph.D. in Psychology, Assistant professor, Assistant professor of the Department of Practical Psychology, Kherson State University, Kherson (Ukraine)

\section{Samkova Olesia}

Ph.D. in Psychology, Senior Lecturer of the Department of Practical Psychology, Kherson State University, Kherson (Ukraine)

\section{DEVELOPMENT OF STUDENTS' SELF-CONSCIOUSNESS BY THE MEANS OF UKRAINIAN LITERATURE}

\section{SUMMARY}

Today, an individual's spiritual development is particularly important for Ukraine. The system of values can effect on successful character education of young people under the condition when the educational process will be performed in the national direction. First of all, it provides the formation of the young generation's spirituality within the context of national consciousness and self-consciousness.

Language, history, beliefs, folklore, art, traditions and customs, symbolism, signs are often called among the components of the national school. To the greatest extent, almost all of these components are displayed in literature, which can be considered a universal space-time art form. Such universality is created through language the language is able to convey temporal, spatial, colour, relief, and all sorts of other features of objects and phenomena. Literature has the most powerful influence on the development of human spirituality and national self-consciousness. 
The educational experiment was performed with the purpose to verify effectiveness of literary and esthetical, ideological and emotional influence of the works of national (Ukrainian) literature and other subjects of the academic cycle of Ukrainian studies on national feelings, thoughts, values, ideals and, in the same way, on the students' self-consciousness development.

The performed educational experiment and the following statistical analysis of its results showed conclusively that the in-depth study of Ukrainian literature, language, and other disciplines of Ukrainian cycle, the courses of pedagogy, psychology, cultural studies, training courses and educational work that strengthen the national orientation influence greatly on an individual's emotional and sensitive sphere, and through it on their intellectual and morally-valuable spheres, which effectively contributes to the development of the students' national selfconsciousness.

Key words: national consciousness and self-consciousness, civic consciousness (civicizm), spirituality, Ukrainian literature, development. 